\title{
Short and long-term results of percutaneous endoscopic gastrostomy
}

\section{Perkutan endoskopik gastrostomi yerleştirilen hastaların kısa ve uzun dönem sonuçlart}

\section{Yaşar Tuna*, Adil Duman}

Department of Gastroenterology (Y. Tuna, MD), Akdeniz University School of Medicine TR07058 Antalya, Department of Gastroenterology (A. Duman, MD), Antalya Teaching and Research Hospital, TR- 07100 Antalya

\begin{abstract}
Aim. Percutaneous endoscopic gastrostomy is the most common method of long-term enteral nutrition. The aim of this study is to evaluate the short and long term efficacy and complications of percutaneous endoscopic gastrostomy. Methods. We included 172 patients who underwent percutaneous endoscopic gastrostomy procedure between 2004 and 2010 in the Gastroenterology Clinic of Akdeniz University. Nutritional status was evaluated on the basis of albumin levels at the sixth month. Patients were evaluated for local and systemic complications of percutaneous endoscopic gastrostomy. Results. Sixty-nine $(40.1 \%)$ patients who underwent percutaneous endoscopic gastrostomy procedures died due to their primary diseases. Percutaneous endoscopic gastrostomy was placed for stroke in 49 patients, for dementia in 32 patients, for posttraumatic encephalopathy in 53 patients, for post-anoxic encephalopathy in 6 patients, for malignant disorders in 30 patients, and for menigoencephalitis in 2 patients. Patients were evaluated for local and systemic percutaneous endoscopic gastrostomy tube complications. The systemic complications consisted of three cases with peritonitis, two bleeding episodes, nine cases with aspiration pneumonia, four cases with dislocation of catheter, and six cases with abscess of abdominal wall. The local complications consisted of seventeen cases with local wound erythema; fifteen patients had leakage of gastric contents, four cases with granuloma formation, and three cases with pain at percutaneous endoscopic gastrostomy site. Mean albumin level of patients at the six month was $3.2 \mathrm{gr} / \mathrm{dL}$. Removal of percutaneous endoscopic gastrostomy due to return of ability to swallow was observed in ten patients. Conclusion. Percutaneous endoscopic gastrostomy is a safe and effective method which accesses to the gastrointestinal tract when performed according to the guidelines. Complications associated with percutaneous endoscopic gastrostomy are well described and are usually local, but major rare events require surgery or result in death. It is safe in terms of complications. Indications and introduction procedures should be standardized. Follow-up by a dietician or specialist nurse could potentially bridge the gap between primary care and hospitals.
\end{abstract}

Keywords: Gastrostomy, indications, complications

\section{Özet}

Amaç. Perkutan endoskopik gastrostomi en sık kullanılan uzun dönem enteral beslenme metodudur. $\mathrm{Bu}$ çalışmanın amacı perkutan endoskopik gastrostominin kısa ve uzun dönem etkinliği ile komplikasyonlarını değerlendirmektir. Yöntemler. Çalışmaya Akdeniz Üniversitesi Gastroenteroloji Kliniği' nde 2004-2010 yılları arasında perkutan endoskopik gastrostomi takılmış 172 hasta dahil edildi. Hastaların beslenme yeterliliği 6 . aydaki serum albumin düzeylerine göre değerlendirildi. Hastalar perkutan endoskopik gastrostominin lokal ve sistemik komplikasyonları açısından değerlendirildi. Bulgular. Perkutan endoskopik gastrostomi takılan hastaların 69(\% 40.1)'unun ölümü primer hastalığına bağlıydı. Hastaların 49'una inme, 32'sine demans, 53'üne postravmatik ensefalopati, 6'sına postanoksik ensefalopati, 30'una malignite, ve 2'sine meningoensefalit nedeniyle perkutan endoskopik gastrostomi işlemi uygulandı. Hastalarda lokal ve sistemik perkutan endoskopik gastrostomi tüpü komplikasyonları değerlendirildi. Sistemik komplikasyon olarak; 3 hastada peritonit, 2 hastada periton boşluğuna kanama, 9 hastada aspirasyon pnömonisi, 4 hastada perkutan endoskopik gastrostomi dislokasyonu, ve 6 hastada karın duvarı absesi gelişti. Lokal komplikasyonlar; 17 hastada lokal yara yeri eritemi, 15 hastada 
perkutan endoskopik gastrostomi yerinde sızınt1, 3 hastada perkutan endoskopik gastrostomi yerinde ağrı, 4 hastada granulom oluşumu ve 11 hastada balon inmesi nedeniyle perkutan endoskopik gastrostomi çıkması gerçekleşti. Hastaların 6. ayda ortalama serum albumin değeri 3.2 gr/dL olarak saptandı. 10 hastanın yutkunma refleksi geri geldiği için' perkutan endoskopik gastrostomileri çekildi. Sonuç. Perkutan endoskopik gastrostomi rehberlerde belirtilen kurallara uygun şekilde yapıldığında gastrointestinal traktüse erişim sağlayan güvenli ve etkin bir yöntemdir. Perkutan endoskopik gastrostomi yerleştirilmesine bağlı komplikasyonlar iyi tanımlanmış olup genellikle lokaldir ancak bazı nadir durumlar cerrahi gerektirebilir veya ölümle sonuçlanabilir. Komplikasyonlar açısından işlem güvenlidir. Endikasyonlar ve giriş işlemleri standardize edilmelidir Hastaların bir diyetisyen ya da özel bir hemşire tarafından izlemi; birinci basamak sağlık hizmetleri ve hastaneler arasında potansiyel bir köprü kurulmasını sağlayabilir.

Anahtar sözcükler: Gastrostomi, endikasyonlar, komplikasyonlar

Geliş tarihi/Received: December 21, 2010; Kabul tarihi/Accepted: April 04, 2012

\section{*Corresponding author:}

Dr. Yaşar Tuna, Gastroenteroloji Anabilim Dalı, Akdeniz Üniversitesi Tıp Fakültesi TR- 07058 Antalya. E-mail: yasartuna61@ @hotmail.com

\section{Introduction}

Percutaneous endoscopic gastrostomy (PEG) feeding has become the most common method of choice for feeding patients with long-term swallowing difficulties. It has been found to be beneficial in patients with diseases originating from neurological disorders [1-5]. Advances in both the treatment of many head and neck cancers and gastrointestinal malignancies, as well as PEG technologies are resulting in more favorable results. PEG does not require general anesthesia and laparotomy, and is associated with shorter hospital admission and lower costs [6]. However, PEG tubes also have disadvantages and potential complications related to both the introduction procedure and the prolonged stay of a foreign body in the abdominal wall. Due to their safety profile, PEGs are considered to be the preferred route for long-term nutrition support in those individuals who have a functional gastrointestinal tract. Complications associated with PEG placement are well described and are usually minor, but major events requiring surgery or resulting in death do occur [7-9]. In our study we present the efficacy of PEG and the frequency of complications related to PEG for various indications.

\section{Materials and methods}

We analysed 172 patients who underwent PEG procedure between 2004 and 2010 in the gastroenterology clinic of Akdeniz University. The indications for PEG were made by the gastroenterology consultant who examined the patient. PEG tubes were placed using the pull method after local anesthesia of the abdominal wall at the side of transillumination [10]. All gastrostomy kits were made of polyurethane and 20-Fr PEG kits. The most commonly performed are the push and pull techniques. Patients who were not currently receiving antibiotics were applied a single dose of IV antibiotics (a third-generation cephalosporin) before the procedure. Data about gender, age, PEG indications, local and systemic complications were collected from file system of the hospital. Absolute contraindications were peritoneal dialysis, gastric outlet stenosis, and ascites. Platelet count, prothrombin time and partial thromboplastin time were checked. All patients were subsequently monitored by dieticians of the hospital nutrition team. Attention was given to wound and tube care as well as to feeding. PEG tubes were no longer introduced in patients with a life expectancy less than a month. Complications were divided as major and minor [11]. Systemic complications were defined as those requiring PEG tube removal and/or hospital admission, such as peritonitis, bleeding into peritoneum, aspiration pneumonia, dislocation of catheter, and abdominal wall abscess. Local 
complications were described after a gastroenterologist was called to see the patient. These included transient wound infection, mild stromal leakage, pain requiring medication, and incorrect removal of catheter. Nutritional status was evaluated on the basis of albumin levels.

\section{Results}

We studied 172 patients, 112 men and 60 women. The mean age of patients was 53.48 years (range 10-89 years). PEG were placed in 49 (28.5\%) patients for stroke, $32(18.6 \%)$ patients for dementia, $53(30.8 \%)$ patients for posttraumatic encephalopathy, 6 (3.5\%) patients for post-anoxic encephalopathy, $30(17.4 \%)$ patients for malign disorders, and 2 (1.2\%) patients for menigoencephalitis (Table 1). A total of $40.1 \%$ of the patients who were underwent PEG procedures died due to their primary diseases. Mean albumin level of patients at the sixth month was $3.2 \mathrm{gr} / \mathrm{dL}$. The mean length of time that the PEG had been in place was 31 months (range 1-96 months). Removal of PEG due to return of ability to swallow was applied in $10(5.8 \%)$ patients. Patients were evaluated for local and systemic PEG tube complications (Table 2).

Table 1. Characteristics of patients receiving percutaneous endoscopic gastrostomy.

\begin{tabular}{ll}
\hline Patients & $\mathbf{n}$ \\
\hline Total number & 172 \\
\hline Sex & 112 \\
\hline Male & 62 \\
Female & $53.48(10-89)$ \\
Mean age year (range) & $102(59.3 \%)$ \\
Alive patients & $69(40.1 \%)$ \\
Dead patients & $3.20 \pm 0.70$ \\
Mean albumin levels & \\
\hline Indications for PEG & $49(28.5 \%)$ \\
\hline Stroke & $32(18.6 \%)$ \\
Dementia & $53(30.8 \%)$ \\
Post-traumatic encephalopathy & $30(17.4 \%)$ \\
Tumor & $6(3.5 \%)$ \\
Post-anoxic encephalopathy & $2(1.2 \%)$ \\
Menigoencephalitis & $10(5.8 \%)$ \\
Removal of PEG due to return of ability to swallow
\end{tabular}

Table 2. Percutaneous endoscopic gastrostomy related complications of patients.

\begin{tabular}{ll}
\hline Local complications & \\
\hline Local infection & $17(9.9 \%)$ \\
Leakage along the tube & $15(8.7 \%)$ \\
Granuloma & $4(2.3 \%)$ \\
Abdominal pain at PEG site & $3(1.7 \%)$ \\
Deflated balloon & $11(6.4 \%)$ \\
\hline Systemic complications & $3(1.7 \%)$ \\
\hline Peritonitis & $2(1.2 \%)$ \\
Bleeding to peritoneum & $9(5.2 \%)$ \\
Aspiration pneumonia & 0 \\
Pneumonia peritonitis(What does pneumonia peritonitis mean?) & $4(2.3 \%)$ \\
Dislocation of catheter & $6(3.5 \%)$ \\
Abdominal wall abscess &
\end{tabular}

Totally systemic complications were seen in $24(13.9 \%)$ of patients. The systemic complications consisted of three cases with peritonitis, two bleeding episodes, nine cases with aspiration pneumonia, four cases with dislocation of catheter, and six cases with abscess of abdominal wall. The systemic complications did not lead to laparotomy. Local 
complications developed in $50(29 \%)$ patients. Seventeen patients suffered from local infection after procedure. Fifteen patients had leakage of gastric contents along-side tube. Granuloma formation was seen in four patients, and three patients developed pain at PEG site. These symptoms were treated conservatively; local wound care, antibiotics and analgesics were applied. Data era was presented as numbers and percentage or mean $\pm \mathrm{SD}$, as appropriate.

\section{Discussion}

Optimal feeding is essential for patients requiring intensive treatment and patients with persistent inadequate oral intake. The patients in our study group had different etiologies. The most common of the central nervous system indication is post-traumatic encephalopathy. The development of the PEG procedure and standardized PEG kits was an important technological advance in the enteral access field. PEG has revolutionized as the approach to long-term enteral nutrition and it has been accepted as an effective and safe procedure. In our study, the incidence of systemic complications varied from $1.2 \%$ to $5.2 \%$, while local complications varied from $3 \%$ to $17 \%$. In the literature, procedure related mortality rate was reported to be between $1 \%$ and $3 \%[11,12]$. The incidence of complications in previous series varied from 5\% to 55\% [11, 13-15]. Most studies have suggested that complications are more likely to occur in elderly patients with comorbid illnesses [16]. Wound infections more likely occur when a PEG is placed through a contaminated procedure field or with a poor technique in debilitated patients. Most PEG wound infections will respond to a first generation cephalosporin or a quinolone [17]. In patients with longstanding PEG tubes, an ulcer may develop underneath the internal PEG tube bolster or on gastric wall. This often responds to loosening of the external bolster. Leakage of gastric contents along-side tube usually occurs within the first few days after PEG placement. It is more likely to occur in malnourished patients. Our patients with minimal leakage of gastric contents were treated conservatively. Early follow-up endoscopy may interfere with the formation of a fistulous tract and thus may induce leakage [18].Some patients develop nausea and vomiting after PEG placement, which may be due to transient gastroparesis [19]. Hemorrhage following PEG tube placement is rare. Most bleeding can be controlled by simple pressure over abdominal wound. PEG tubes can migrate forward into the duodenum and cause gastric outlet obstruction [20]. This complication can be avoided by making sure the external bolster remains at the same centimeter mark on the gastrostomy tubes after initial proper positioning. It is now generally considered that, in patients who have head and neck cancer receiving radiation and chemotherapy, PEG placement has become standard of care before initiating treatments. In previous reports, the incidence of wound and nosocomial infections are increased in patients with PEG when compared with patients undergoing gastric bypass surgery $[21,22]$. Prevention from complications depends on adequate patient selection, antibiotic prophylaxis, procedure techniques and close follow-up. Patients hospitalized with acute illness, and those with a malignancy and low body-mass index, are at more risk of PEG complications [23]. The risk of aspiration pneumonia may be lower in patients fed through PEG tubes compared to those fed with nasogastric tube [24]. Aspiration pneumonia occurred in 9 patients (5.2 percent) in our study. Patients with PEG tubes and regurgitation who were fed directly into small bowel may have a lower risk of aspiration compared with with those fed via the stomach. Necrotizing fasciitis is a rare complication of PEG placement [25, 26]. Patients with diabetes, wound infections, malnutrition, and a poor immune system are at increased risk. Wound care is important following PEG tube placement. Peritonitis has been reported from leakage of gastric contents from the gastrostomy site into the peritoneal cavity [27]. In our study the mean length of time that the PEG had been in place was 31 months. With respect to follow-up of patients with a PEG tube, nutrition team appeared very valuable. Such team can ensure intensive individual nutritional advice, as well as diagnosing problems at early stage. The effectiveness of PEGs should be determined only from studies in which the measured outcomes are realistic achievable. Many of the studies described above included patients 
who were severely debilitated or had a short life-expectancy because of their underlying illnesses, making it difficult to appreciate the benefit that a PEG may have offered.

In conclusion, PEG tube placement allows optimal feeding for prolonged periods with the occasional need for replacement. It is safe in terms of complications. The need for PEG placement must be assessed in appropriate patients. Indication and introduction procedures should be standardized and should preferably not include acutely ill patients and those with a life expectancy of less than 4 weeks. Follow-up by a dietician or specialist nurse could potentially bridge the gap between primary care and hospitals.

\section{References}

1. James R, Gines D, Menlove A, Horn SD, Gassaway J, Smout RJ. Nutrition support (tube feeding) as a rehabilitation intervention. Arch Phys Med Rehabil 2005; 86: s82-s92.

2. Rimon E, Kagansky N, Levy S. Percutaneous endoscopic gastrostomy; evidence of different prognosis in various patient subgroups. Age Ageing 2005; 34: 353-7.

3. James A, Kapur K, Hawthorne AB. Long-term outcome of percutaneous endoscopic gastrostomy feeding in patients with dysphagic stroke. Age Ageing 1998; 27: 671-6.

4. Mazzini L, Corrà T, Zaccala M, Mora G, Del Piano M, Galante M. Percutaneous endoscopic gastrostomy and enteral nutrition in amyotrophic lateral sclerosis. J Neurol 1995; 242: 695-8.

5. Procaccini NJ, Nemergut EC. Percutaneous endoscopic gastrostomy in the patient with amyotrophic lateral sclerosis: risk vs benefit? Pract Gastroenterol 2008; 2434.

6. Wollman B, D'Agostino HB, Walus-Wigle JR, Easter DW, Beale A. Radiologic, endoscopic, and surgical gastrostomy: an institutional evaluation and metaanalysis of the literature. Radiology 1995; 197: 699-704.

7. Patel PH, Thomas E. Risk factors for pneumonia after percutaneous endoscopic gastrostomy. J Clin Gastroenterol 1990; 12: 389-92.

8. Short TP, Patel NR, Thomas E. Prevalence of gastroesophageal reflux in patients who develop pneumonia following percutaneous endoscopic gastrostomy: a 24hour $\mathrm{pH}$ monitoring study. Dysphagia 1996; 11: 87-9.

9. McGovern R, Barkin JS, Goldberg RI, Phillips RS. Duodenal obstruction: a complication of percutaneous endoscopic gastrostomy tube migration. Am $\mathrm{J}$ Gastroenterol 1990; 85: 1037-8.

10. Hogan RB, DeMarco DC, Hamilton JK, Walker CO, Polter DE. Percutaneous endoscopic gastrostomy--to push or pull. A prospective randomized trial. Gastrointest Endosc 1986; 32: 253-8.

11. Cortez-Pinto H, Correia AP, Camilo ME, Tavares L, De Moura MC. Long-term management of percutaneous endoscopic gastrostomy by a nutritional support team. Clin Nutr 2002; 21: 27-31.

12. Finocchiaro C, Galletti R, Rovera G, Ferrari A, Todros L, Vuolo A, Balzola F. Percutaneous endoscopic gastrostomy: a long-term follow-up. Nutrition 1997; 13: 520-3.

13. Amann W, Mischinger HJ, Berger A, Rosanelli G, Schweiger W, Werkgartner G, Fruhwirth J, Hauser H. ercutaneous endoscopic gastrostomy (PEG). 8 years of clinical experience in 232 patients. Surg Endosc 1997; 11: 741-4.

14. Larson DE, Burton DD, Schroeder KW, DiMagno EP. Percutaneous endoscopic gastrostomy. Indications, success, complications, and mortality in 314 consecutive patients. Gastroenterology 1987; 93: 48-52.

15. Aschl G, Kirchgatterer A, Allinger S, Hinterreiter M, Hubner D, Kranewitter W, Stadler B, Wimmer L, Knoflach P. Indications and complications of percutaneous endoscopic gastrostomy. Wien Klin Wochenschr 2003; 115: 115-20.

16. Payne KM, King TM, Eisenach JB. The technique of percutaneous endoscopic 
gastrostomy. A safe and cost-effective alternative to operative gastrostomy. J Crit Illn 1991; 6: 611.

17. Mitchell SL, Kiely DK, Lipsitz LA. The risk factors and impact on survival of feeding tube placement in nursing home residents with severe cognitive impairment. Arch Intern Med 1997; 157: 327.

18. Mathus-Vliegen LM, Koning H. Percutaneous endoscopic gastrostomy and gastrojejunostomy: a critical reappraisal of patient selection, tube function and the feasibility of nutritional support during extended follow-up. Gastrointest Endosc 1999; 50: 746-54.

19. Dulabon GR, Abrams JE, Rutherford EJ. The incidence and significance of free air after percutaneous endoscopic gastrostomy. Am Surg 2002; 68: 590.

20. Fischer LS, Bonello JC, Greenberg E. Gastrostomy tube migration and gastric outlet obstruction following percutaneous endoscopic gastrostomy. Gastrointest Endosc 1987; 33: 381.

21. Printen KJ, Paulk SC, Mason EE. Acute postoperative wound complications after gastric surgery for morbid obesity. Am Surg 1975; 41:483-5.

22. Choban PS, Heckler R, Burge JC, Flancbaum L. Increased incidence of nosocomial infections in obese surgical patients. Am Surg 1995; 61: 1001-5.

23. Abuksis G, Mor M, Segal N, Shemesh I, Plout S, Sulkes J, Fraser GM, Niv Y. Percutaneous endoscopic gastrostomy: high mortality rates in hospitalized patients. Am J Gastroenterol 2000; 95: 128-32.

24. Fay DE, Poplausky M, Gruber M, Lance P. Long-term enteral feeding: a retrospective comparison of delivery via percutaneous endoscopic gastrostomy and nasoenteric tubes. Am J Gastroenterol 1991; 86: 1604.

25. Cave DR, Robinson WR, Brotschi EA. Necrotizing fasciitis following percutaneous endoscopic gastrostomy. Gastrointest Endosc 1986; 32: 294.

26. Martindale R, Witte M, Hodges G, Kelley J, Harris S, Andersen C. Necrotizing fasciitis as a complication of percutaneous endoscopic gastrostomy. JPEN J Parenter Enteral Nutr 1987; 11: 583.

27. Honjo S. A mother's complaints of overeating by her 25 -month-old daughter: a proposal of anorexia nervosa by proxy. Int J Eat Disord 1996; 20: 433. 